\title{
第51回 日本視能矯正学会
}

\section{教育セミナー}

\section{5. 眼底写真}

\author{
堀内康史
}

群馬大学

眼底カメラの性能は向上し、きれいな眼底写 真を簡単にとる事ができるようになった。しか し、「その眼底写真から何を診たいのか」、を考 えないで撮影すると、場合によっては肝心な情 報が含まれない失敗写真を撮ってしまうことに なる。一番わかりやすい例は病変部そのものが 写っていない場合である。眼底カメラのほとん どは、眼底の後極

部が写るようにできている。固視標があって、 被検者がそこを固視することで黄斑部を中心に 血管アーケード内部とその周辺が主に写真に描 出される。しかし、脈絡膜腫瘍や網膜細動脈瘤 などは必ずしも後極にあるわけではない。また、 広範な病変部を記録したい場合、パノラマ撮影 を行うが、全範囲を撮つたつもりが撮れておら
ず、欠損部のあるパノラマ写真になってしまう などの失敗もある。そして、これらの失敗も、 カラー眼底撮影なら、すぐ撮り直し可能だが、 フルオレセインやインドシアニングリーンの蛍 光眼底造影となると、そうはいかない。造影検 査は被検者に負担が大きい。造影剤を注射する 痛みはもちろんだが、造影剤の副作用によるシ ヨックのリスクを負う検査である。

この検査で何を診たいのか、よく理解してか ら臨まないと検査が無駄になってしまうことも ある。本セミナーでは、こういった失敗を避け られるよう、基本的な撮影のポイント、蛍光眼 底造影の原理、カラー眼底写真と蛍光眼底写真 の「その眼底写真から何を診たいのか」につい てふれる。

抄録のみを掲載しています。 